\title{
STRATEGI PENYEBARAN TRADISI ISLAM PADA MASYARAKAT JAWA
}

\author{
Sayfa Aulia Achidsti \\ Universitas Gadjah Mada (UGM) Yogyakarta \\ Jl. Bulaksumur (+62-274) 64919336 Yogyakarta 55281 \\ E-mail: achidsti_sayfa@yahoo.com \\ HP. +62-85293111066
}

Abstract: This paper intends to present a brief understanding of the general condition of the relationship between religion and society in Indonesia. No longer any prophet as role model of Islam led to debate about Islam as a doctrine and religious practice, which is in the course of time the social and political aspects are often greatly influenced its development. The condition is not as simple as when the Prophet was alive. Islam is moving developments not only in the Middle East means the area has resulted in the distance from the center of Islam. Contextualization in terms of the physical form of Islam to be logical here, namely local community as a body, and Islam as the content.

Abstrak: Tulisan ini bermaksud menyajikan pemahaman singkat mengenai kondisi umum hubungan agama dan masyarakat di Indonesia. Tiadanya Nabi sebagai panutan Islam menyebabkan perdebatan mengenai Islam sebagai sebuah doktrin dan praktik agama, yang semakin ke sini aspek sosial dan politiknya seringkali sangat mempengaruhi perkembangannya. Dengan demikian, kondisi pada saat ini tidak sesederhana pada saat Nabi masih hidup, dengan pertumpuannya pada al-Qur'an, Hadis, dan rukun Islam serta rukun imannya. Perkembangan Islam yang bergerak tidak hanya di daerah Timur Tengah berarti telah menyebabkan terjadinya jarak dengan pusat Islam. Kontekstualisasi dalam hal bentuk fisik Islam menjadi logis di sini, di mana lokalitas masyarakat setempat sebagai tubuh dan Islam sebagai isi.

Kata Kunci: Agama, Islam, Tradisionalisme, Masyarakat, Indonesia.

\section{A. Pendahuluan}

Perkembangan Islam di Indonesia dipengaruhi oleh kondisi perkembangan sosial politik Islam di wilayah Timur Tengah sebagai pusat penyebaran Islam. 
Namun demikian, Sunni, sebagai mazhab mayoritas umat muslim di dunia, juga menjadi mazhab mayoritas muslim di Indonesia. Dalam hal ini, momen kemenangan Ibn Sa'ud sebagai khalifah di semenanjung Arab pada awal tahun 1920-an, memiliki andil cukup besar dalam membentuk bentuk Islam hingga pada saat ini, dengan kemunculan pertemuan wacana dua kelompok besar Islam di Indonesia, antara tradisionalis dan modernis.

Untuk kasus yang satu ini, dikotomi pemahaman antara agama dan tradisi lokal masyarakat, tidak hanya terjadi di Indonesia, namun juga terjadi di hampir semua negara. Ini disebabkan karena Islam sebagai agama yang dianut oleh berjuta orang, memiliki pemahamannya masing-masing dalam cara berdakwahnya: menentang adat dan tradisi secara fundamental, atau melihat dua hal tersebut sebagai hal yang tidak terlalu penting dan lebih memilih pada penyebaran Islam secara esensi, yaitu pada pola pikir dan semangat keislamannya.

Tulisan ini mengungkap tentang Islam di Indonesia yang secara isi dipengaruhi oleh nilai-nilai lokal, juga dipengaruhi oleh Timur Tengah sebagai pusat perkembangan sosial politik Islam. Perkembangan Islam di Nusantara, pada mulanya, juga tidak lepas dari peranan Walisongo dalam sistem kemasyarakatan, yang selaras dengan nilai lokal masyarakat. Pemahaman mengenai Islam dan nilai lokal inilah yang akan menjadi titik pembicaraan untuk melihat dinamika struktur sosial masyarakat Indonesia.

\section{B. Walisongo: Penyebar Islam di Jawa}

Walisongo sebagai pengantar pemahaman atas perkembangan Islam di Nusantara memberikan gambaran gerakan dakwah para Sunan sebagai pengubah sistem budaya memasukkan dirinya ke dalam masyarakat yang telah memiliki Hindu-Budha sebagai agama yang telah tersebar dan dianut sebelumnya. Gerakan dakwah model Walisongo inilah yang kemudian digunakan para kiai saat ini untuk mendekati dan masuk dalam sistem masyarakat, lalu menginternalisasikan konsepsi yang dibawa kiai secara persuasif.

Sebagai tokoh yang membawakan konsepsi baru mengenai kehidupan dan pola aktivitas berlandaskan norma dan nilai Islam, para Sunan dapat dikatakan sebagai pemegang peran pengubah dalam masyarakat. Dalam gerakannya, yang menjadi landasan utama pengubahan dalam masyarakat adalah sistem. Oleh karena itu, gerakan intelektual dan budayalah yang menjadi penekanan gerakan dakwah Walisongo di tanah Jawa ini. Dalam tulisan sejarah, Sunan

\footnotetext{
${ }^{1}$ Terdapat beberapa penyebutannya, yang oleh beberapa pihak disebut orang berbeda, namun oleh pihak lain dikatakan sebagai orang yang sama hanya perbedaan penyebutannya
} 
Maulana Malik Ibrahim ${ }^{1}$ adalah salah satu dari sembilan wali yang datang pertama kali, sekitar abad ke-15, yang diyakini memiliki garis keturunan dari Nabi (Sofwan, 2004). Masa Sunan Maulana Malik Ibrahim ini ada pada periode mulai menurunnya kekuatan Kerajaan Majapahit setelah dilanda banyak pemberontakan dan perang saudara. Pemerintahan yang mulai kacau mengakibatkan ketidakstabilan di tingkatan masyarakat, yang paling tampak adalah banyaknya penjarahan dan merebaknya perampok. Terdapat satu kisah populer di sini, yaitu ketika para murid Sunan berhadapan dengan perampok yang kemudian justru menjadi pengikut dan mengabdikan dirinya sebagai murid Sunan. Kemampuan Sunan yang menarik masyarakat pada saat itu yang mampu mendatangkan hujan pada saat kekeringan, yang dikatakannya atas izin Allah. Sunan Maulana Malik Ibrahim mendirikan pesantren di daerah Leran (Gresik, Jawa Timur).

Penyebar Islam lain dalam Walisongo adalah Sunan Ampel yang bernama asli Raden Rahmat yang memiliki pesantren di daerah Ampel Denta (Surabaya) yang sekaligus menjadi pusat penyebaran agama Islam-nya. Di tempat inilah kemudian muncul Raden Paku (Sunan Giri), ${ }^{2}$ Raden Patah (sultan pertama Kerajaan Demak), Raden Makdum Ibrahim (putranya, yang kelak disebut dengan Sunan Bonang), dan Syarifuddin (Sunan Drajat). Adapun Raden Rahmat sendiri adalah putra raja Campa, sebuah kerajaan di wilayah Kamboja dan sekitarnya. Dalam hal ini, menurut Babad Tanah Jawi, dituliskan bahwa Raden Rahmat merupakan keturunan dari Maulana Malik Ibrahim (terdapat beberapa versi mengenai garis keturunan ini) (Sofwan, 2004). Raden Rahmat menikah dengan Dewi Condrowati (Nyai Ageng Manila), putri dari Arya Teja, seorang adipati di Tuban; pernikahan ini melahirkan beberapa keturunan yang kelak dua di antaranya menjadi Sunan Bonang dan Sunan Drajad.

Dakwah Sunan Bonang menjadi salah satu yang khas dari gaya penyebaran agama yang ditiru para kiai hingga saat ini, yaitu dengan hiburan. Dalam sisi keturunan, Sunan Bonang adalah putra dari Sunan Ampel, cucu dari Maulana

saja; yaitu Syekh Maghribi atau Makdum Brahim Asmara (kemungkinan sebagai penyebutan 'Samarkand' oleh lidah orang Jawa yang menjadi 'Asmarakandi'). Dari mana kedatangannya pun masih diperdebatkan, seperti juga Walisanga yang lain. Untuk Sunan Maulana Malik Ibrahim ini, terdapat dua daerah yang diyakini sebagai tempat di mana dia datang, yaitu dari Campa atau dari Samarkand (Asia Tengah). Namun demikian, ada pula anggapan bahwa dia dari Samarkand, yang bermukim dulu di Campa.

${ }^{2}$ Sunan Giri (Raden Paku) adalah putra dari Maulana Ishak dan Dewi Sekardadu yang merupakan putri dari kelas penguasa pada saat itu. Versi lain mengatakan bahwa Sunan Giri adalah putra dari Ishak Maksum yang merupakan anak dari Maulana Malik Ibrahim. 
Malik Ibrahim. Seperti sebutannya, Raden Makdum Ibrahim menggunakan media kesenian musik untuk mengumpulkan orang-orang mendekati pondokannya, mendengarkan pagelaran musik (bonang) yang sedikit-sedikit diberikan dakwah Islam di situ, pemberian nilai-nilai, dan pemahaman ulang tentang makna kehidupan sesuai dengan konsep yang dibawa Raden Makdum. Sunan Bonang menyebarkan Islam di daerah Tuban, Pati, Madura, dan Bawean, walaupun tidak menutup kemungkinan bahwa daerah yang terislamkan selain it u juga oleh sebab peranan Sunan Bonang. Para penyebar Islam pada saat itu tidak jarang untuk selama beberapa saat mengembara sekaligus menyebarkan Islam di setiap daerah yang dilaluinya.

Sunan Bonang juga dikenal sebagai penggubah “Suluk Wijil” dan nyanyian "Tombo Ati"3 yang terkenal dan masih dinyanyikan serta diajarkan hingga sekarang. Hingga saat wafat, para pengikutnya di Tuban menginginkan jenazahnya dimakamkan di Tuban, namun begitu pula para pengikutnya di Bawean yang menginginkan jenazahnya untuk dimakamkan di Bawean. Kisah yang berkembang adalah pada suatu malam murid-muridnya di Tuban datang ke Bawean dan membongkar makam Sunan Bonang untuk dipindahkan ke Tuban, yang hingga kini terdapat makamnya di dekat Masjid Agung Tuban. Pada kenyataannya, makam yang berada di Bawean masih diyakini jenazahnya masih ada pula di situ.

Sunan Kalijaga mungkin dapat dibilang sebagai salah satu Sunan yang paling populer dalam penulisan sejarah Walisongo. Hal ini kemungkinan sebab kisah heroik dan beragam, yang disebabkan lebih banyak naskah-naskah klasik yang memuat nama Sunan Kalijaga sehingga sejarah mengenainya lebih mudah ditelusuri. Sunan Kalijaga (bernama muda Raden Said, seorang putra Tumenggung Wilatikta, Adipati Tuban) menggunakan media dakwah yang hampir sama dengan Sunan Bonang, yaitu lewat kesenian. Walaupun begitu, Sunan Kalijaga lebih populer dicitrakan sebagai "sunannya rakyat" karena dalam berbagai cerita dikisahkan bahwa Sunan Kalijaga selalu dekat dengan rakyat, memilih untuk berpakaian sama dengan orang awam yang terkadang sulit membedakan antara

\footnotetext{
${ }^{3}$ Lirik lagu yang merakyat ini diberi ajaran-ajaran Islam. Lirik tembang "Tombo Ati” ("Tombo ati iku ana lima perkara. Kaping pisan, maca Qur'an sak maknane. Kaping pindho, solat wengi lakonono. Kaping telu, wong kang sholeh kumpulana. Kaping papat, kudu weteng ingkang luwe. Kaping lima, zikir wengi ingkang suwe. Salah sawijine, sapa bisa ngelakoni. Mugi-mugi, Gusti Allah ngijabahi"). Lirik yang benar-benar baru dalam hal ajaran ini dibungkus sedemikian rupa dalam hal irama lagu yang familiar bagi telinga orang Jawa. Dengan demikian, hal yang pertama dituju bukanlah langsung pada pelaksanaan ajaran, namun dengan disenandungkannya lagu ini terus-menerus karena kemudahan penyanyiannya, diharapkan orang-orang kelak akan juga melaksanakan isi lagu tersebut.
} 
penyebar agama dengan orang bawah pada umumnya. "Hasil" yang didapat Sunan Kalijaga pun disebut sebagai kesuksesan paling signifikan dalam pendekatannya terhadap masyarakat Jawa secara umum. Kesenian wayang kulit diperkenalkan oleh Sunan Kalijaga dengan mengambil cerita-cerita dari tanah India yang dimodifikasi sesuai dengan ajaran-ajaran Islam yang dibawakan olehnya. Oleh karena cerita-cerita tersebut diambil dari India, yang berarti sarat dengan bentuk mitos-mitos Hindu, dalam segi bentuk, wayang kulit dapat langsung menarik hari orang awam.

Sisi impresivitas dalam hal bentuk luar cerita itu digunakan Sunan Kalijaga sebagai upaya penarikan simpati, yang kemudian modifikasi atas cerita tersebut adalah sebuah dakwah Islam. Salah satu yang terkenal dalam cerita pewayangan adalah Jimat Kalimasada, di mana siapa pun yang memilikinya, adalah sebuah keniscayaan bahwa kemakmuran dunia dan kehidupan kelak akan diperolehnya. Jimat ini, dalam cerita, dimiliki oleh salah seorang dari Pandawa, yang menjadi perebutan semua orang. Jimat Kalimasada ini sebenarnya merupakan penjabaran atas hakikat "kalimat syahadat". Kesuksesan penyebaran Islam yang dilakukan oleh Sunan Kalijaga adalah prinsipnya yang agak sedikit berbeda secara teknis dalam memandang adat-istiadat setempat dibandingkan dengan para penyebar Islam yang lainnya. Sunan Kalijaga justru menjaga kebiasaan setempat, dan tidak bersikap anti terhadap pola tingkah-laku masyarakat. Bahkan, dalam pengajaran lafal-lafal Arab pun, kesulitan lidah orang Jawa untuk mengucap kosa kata Arab begitu dimaklumi. Dengan tingkat toleransi yang semacam itu, orang awam tidak terlalu berpikir panjang akan adanya kesulitan beradaptasi dengan ajaran baru yang dibawanya itu. Wali yang menggunakan media wayang lainnya adalah Sunan Giri, yang dianggap sebagai penemu wayang gedog, yang mengkhususkan diri dalam kisah-kisah Panji. Sunan Kudus, sebagai penemu wayang golek, yang menampilkan ceritacerita Menak (Lombard, 2008b: 341).

Selain dengan wayang kulit dan media lagu, seperti di atas tersebut, internalisasi ajaran Islam pun dilakukan dengan model hiburan rakyat yang dilakukan dalam skala besar, misalnya saja pasar rakyat atau syukuran terhadap beberapa momen tertentu. Perayaan pasar rakyat "Sekaten" adalah salah satu contohnya, yang hingga saat ini masih dikenal masyarakat secara luas. Walaupun jika dilihat dari sisi siapa yang memulai untuk mengadakan tradisi ini adalah bukan pada masa Walisongo, namun gaya/model dalam menyebarkan nuansa dan tradisi Islam sangat erat dan mirip dengan model penyebaran agama yang digunakan para Wali. Perayaan Sekaten ini adalah sebuah pasar rakyat yang diadakan selama beberapa pekan, biasanya satu bulan lebih, untuk 
memperingati hari lahir Nabi Muhammad SAW. Sekaten diadakan setiap tanggal 5 dalam penanggalan bulan Jawa (Mulud), yang dalam penanggalan Islam (tahun Hijriah) disebut bulan Rabiul Awal. Sekaten dimulai oleh Sultan Hamengkubuwana I, pendiri Keraton Yogyakarta, yang salah sat unya dan paling penting tujuannya adalah menarik perhatian warganya untuk lebih dekat dengan Islam.

\section{Tradisionalisme Islam di Indonesia}

Pada dasarnya, pola yang digunakan oleh kiai dalam mendekati masyarakat dalam rangka menyebarkan pemikirannya masih dapat dibilang sama dengan yang dilakukan oleh para wali pada dulu kala. Hal tersebut disebabkan oleh beberapa hal. Yang paling utama adalah pengaruh dari para wali itu sendiri, di mana penyebaran Islam yang mereka lakukan pada perkembangannya mengalami regenerasi. Proses terjadinya regenerasi juru dakwah inilah yang terjadi di pesantren. Faktor yang berikutnya adalah, para wali, pada masa dakwahnya melakukan gerakan dakwah dengan efektif dengan melalui kedekatan dengan lingkaran kekuasaan setempat. Seperti para pendakwah agama pada umumnya, struktur kekuasaan adalah hal yang diperhitungkan sebagai jalur akses pada sumber daya kekuatan dalam rangka mendukung gerakan dakwah. Dalam sejarah para wali, tidak jarang disebutkan bahwa mereka memiliki hubungan kekerabatan yang dekat dengan para bangsawan kerajaan, bahkan boleh dibilang hampir semuanya memiliki darah keraton pula. Hubungan yang erat, bahkan hubungan darah dengan pihak keraton ini pada umumnya disebabkan oleh perkawinan.

\section{Keyakinan Sebelum Islam}

Persoalan kedekatan para pendakwah dengan lingkaran kekuasaan sebenarnya hanya menjadi penunjang aktivitasnya. Hal ini efektif pada saat kedekatan dengan penguasa membawa perubahan-perubahan kebijakan penguasa tersebut. Pada masa kerajaan-kerajaan Islam (biasa disebut dengan kesultanan), para sultannya melakukan peran sebagai pendakwah untuk penduduknya sendiri, di samping tugas dan perannya sebagai raja. Walaupun tidak dapat dibandingkan dengan gerakan dakwah yang dilakukan para wali, terdapat pula asumsi bahwa keinginan raja untuk bergelar sultan adalah kepentingan politik-ekonomi, namun paling tidak, adanya sultan (raja Islam) adalah faktor pendorong meluasnya ajaran Islam di Nusantara. Masuknya ideide Islam pada sistem keraton adalah keuntungan tersendiri. Penguasa yang pada akhirnya bisa menjadi sejalan dengan ajaran Islam adalah salah satu 
prestasi dalam sebuah dakwah. Hal tersebut seringkali membawa efek positif lanjutan dalam kaitannya dengan dukungan pada gerakan dakwah yang dilakukan. Tidak jarang juga kemudian setelah sistem dalam keraton dapat menerima ide-ide yang dibawa pendakwah, akan mendukung segala kegiat an pendakwah tersebut. Hal yang paling sering dilakukan oleh para penguasa ini adalah membantu dalam hal pembangunan institusi pendidikan keagamaan, baik itu dalam pemberian tanah, hutan dan sumber dayanya, sampai hadiahhadiah yang berharga. Namun, kebanyakan pembangunan pesantren tidak menjadi bantuan yang dilakukan oleh para penguasa. Pada bagian awal telah dijelaskan bahwa upaya yang dilakukan kiai dalam masyarakat adalah membuat masyarakat percaya bahwa segala hal milik kiai dan yang dilakukannya adalah demi masyarakat. Oleh karena itu, pembangunan pesantren pun lebih sering dilakukan dari nol, dengan tenaga dari penduduk setempat itu sendiri.

Penyebaran Islam yang dilakukan para pendakwah memang tidak dapat dibilang mudah. Hampir sama dengan penyebaran agama baru dalam masyarakat yang telah memiliki agama, penerimaan ide tersebut memerlukan waktu yang lama, berikut dengan cara-cara yang kontekstual dengan kondisi setempat. Mulai masuknya Islam di Nusantara pun sebenarnya telah ada sejak abad ke-7 (atau abad pertama dalam tahun Hijriah). Pendapat ini didukung oleh Hamka, dengan alasan adanya berita Cina yang mengisahkan kedatangan ut usan Raja Ta Cheh kepada Ratu Sima. Raja Ta Cheh sendiri adalah Raja Arab, dan khalifah pada saat itu adalah Muawiyah bin Abi Sufyan (Anasom, 2000). Pada kenyataannya, perkembangan pesat dalam penyebaran agama Islam baru terjadi beberapa abad setelahnya, pada saat Walisongo mulai menjalankan dakwahnya di Pulau Jawa. Hal tersebut, pada dasarnya disebabkan oleh telah mengakarkuatnya pengaruh ajaran Hindu-Budha pada masyarakat lokal di Nusantara ini. Walaupun bukan ajaran yang benar-benar asli seperti di India, pengaruh Hindu-Budha dalam masyarakat di Jawa (pada khususnya) cenderung menolak ajaran Islam yang sangat asing bagi mereka.

Dalam penelitian Suparlan, yang mengkritisi Bachtiar at as tanggapannya terhadap Religion of Java karya Geertz, dikatakan bahwa agama orang Jawa bukanlah pemujaan leluhur. Namun, lebih berintikan pada prinsip utama yang dinamakan sangkan paraning dumadi (dari mana manusia berasal, apa dan siapa dia pada masa kini, dan ke mana arah tujuan hidup yang dijalani dan ditujunya). Prinsip ini meliputi dua hal, yaitu konsep mengenai eksistensi dan tempat manusia di alam semesta beserta segala isinya, dan berbagai kegiatan yang berkaitan dengan lingkungan hidup. Dalam hal ini, yang diberi persembahan tidak selalu harus para leluhur, dan tidak semuanya itu digolongkan sebagai 
leluhur. Dalam persembahan sewaktu selametan, misalnya, makanan-makanan yang disajikan kepada makhluk halus tertentu disebutkan jenis-jenis makanannya (Suparlan, 1983).

Perkembangan Islam di luar Jawa sendiri dapat dibilang lebih cepat dan berkembang daripada di Jawa. Hal tersebut dikarenakan halangan para pendakwah Islam dalam menyebarkan ajaran agama tidak terlalu sulit, "hanya" berhadapan dengan tradisi ajaran Hindu-Budha. Namun, Jawa adalah masyarakat beserta sistemnya yang lebih kompleks. Dalam sumber yang berbeda, disebutkan bahwa religiositas masyarakat Jawa terdapat dalam ajaran Kapitayan. Keyakinan yang telah ada pada masa sebelum kedatangan Hindu ini ini lebih menyerupai ketauhidan daripada animisme-dinamisme seperti yang kebanyakan peneliti anggap. Penyebutan sebagai animisme-dinamisme sendiri muncul oleh karena, secara tampilan fisik, ritual yang dilakukan oleh para penganutnya tampak sebagai penyembahan terhadap benda-benda. Secara sederhana, penyembahan benda-benda itu dipahami sebagai pemujaan terhadap kekuat an benda itu sendiri (animisme-dinamisme). Sebenarnya, pada awalnya ajaran Kapitayan justru tidak menyembah benda itu sebagai kekuatan mutlak, namun lebih pada penyembahan Sang Hyang, kekuat an tertinggi. Benda-benda yang terdapat dalam ritual keagamaan, seperti pohon, batu, dan mata air adalah beberapa perwujudan saja dari kekuatan yang maha tinggi Sang Hyang tersebut.

Pendekatan tradisi yang dilakukan oleh Walisongo pada akhirnya membuktikan bahwa ide-ide mereka mengenai ajaran Islam dapat diterima oleh masyarakat. Di Jawa, Islam menghadapi suasana yang kompleks dan halus yang dipertahankan oleh para bangsawan. Oleh karena itu, perkembangan Islam di Jawa menghadapi dua jenis lingkungan budaya. Pertama, budaya pertani lapisan bawah yang merupakan bagian kelompok terbesar dan pada umumnya masih dipengaruhi oleh animisme-dinamisme (yang sebenarnya adalah ajaran Kapitayan). Kedua, kebudayaan di Keraton yang merupakan tradisi filsafat Hindu-Budha yang mengalami akulturasi dengan ajaran-ajaran mistik Jawa (Ridwan, dkk. 2008: 37). Islam yang menyebar di kalangan bawah adalah keberhasilan Walisongo untuk memahami keyakinan Kapitayan (pengakuan terhadap kekuatan tak terlihat yang paling tinggi). Dalam pemahaman Walisongo, hal tersebut hampir mirip dengan ketauhidan dalam ajaran Islam yang mengajarkan keesaan tuhan. Dalam hal ini, ajaran Hindu-Budha yang masuk di kalangan masyarakat pun pada dasarnya telah mengalami "seleksi" dari keyakinan Kapitayan ini. Islam yang dibawa oleh Walisongo adalah Islam tasawuf, yang lebih mengutamakan substansi daripada bentuk fisik. 
Oleh karena itu, perubahan yang diadakan dalam penyebaran agama Islam ini tidak memaksakan perubahan yang drastis, namun perlahan-lahan dan justru cenderung mempertahankan bentuk. Oleh Sunan Bonang, misalnya, salah satu dari Walisongo, upacara Panca Makara ini diubah substansinya namun tetap pada bentuknya. Yaitu terdapat perkumpulan orang yang duduk melingkar, terdapat makanan sebagai tanda syukur kepada Allah, dan mengganti ritual persetubuhan, pertapaan, dan ekstase dengan berdoa pada Allah. "Ma Lima" sebagai istilah yang digunakan dalam penyebutan syarat-syarat Panca Makara pun diubah maknanya sebagai lima larangan "ma", yaitu madat (minuman keras), madon (bermain perempuan), maling (mencuri), main (judi), dan maksiat (perbuatan buruk). Hal tersebut lebih mudah dipahami oleh kalangan masyarakat awam, sekaligus melakukan pemaknaan ulang dalam kaitannya mencegah terjadinya Ma Lima dalam ajaran kuno terjadi kembali. Dengan model perubahan semacam ini, masyarakat tidak terlalu kaget dan terlalu banyak beradaptasi. Dipengaruhi dengan cara pandang tasawuf pula, yang tidak mementingkan bentuk fisik, perubahan-perubahan yang diupayakan oleh Walisongo dalam masyarakat Jawa adalah perubahan pemikiran dan keyakinan, bukan pada perubahan adat dan tradisi yang memang tidak diharuskan dalam Islam.

\section{Perubahan Setelah Masuknya Islam}

Dalam penelitiannya mengenai masyarakat agama di wilayah Kotagede, Yogyakarta, Nakamura mengatakan bahwa terdapat perkembangan kehidupan keberagamaan yang pesat. Praktik-praktik dan ritual keagamaan yang dicampurbaurkan antara Islam dengan tradisi peninggalan Hindu-Budha di Kotagede adalah sebuah perkembangan pemahaman atas pengetahuan keagamaan. Agak berbeda dengan Ali, fungsionaris Muhammadiyah yang menjadi Menteri Agama RI pada tahun 1973-1978, yang mengatakan bahwa politik hanya merupakan perhatian sampingan bagi kehidupan keseharian kebanyakan kaum muslim. Nakamura justru lebih menyukai untuk menyebut perkembangan di Kotagede adalah fenomena yang tidak unik. Nakamura berargumen bahwa gerakan Muhammadiyah di Kotagede adalah manifestasi kontemporer proses kelanjutan sejarah Islamisasi. Terdapat hubungan di dalamnya dengan perubahan-perubahan dalam aspek sosial, ekonomi, dan politik. Dan terakhir adalah perkembangan Muhammadiyah yang mengubah tradisi agama setempat sehingga mendekat lebih erat pada kebenaran Islam (Nakamura, 1983: 1).

Orang memang seringkali memandang gejala perkembangan Muhammadiyah di Kotagede, misalnya, sebagai semacam ledakan sosial dan intelektual. 
Perkembangan di Kotagede adalah hal yang biasa, di mana pada sejumlah tanda memberikan kesan bahwa ada banyak perkembangan yang bersamaan yang mencerminkan gejolak agama dan sosial yang terjadi sendiri-sendiri di tiap daerah namun dalam waktu yang serentak di dalam dan luar Jawa pada satu dasawarsa pertama abad ini. Perkembangan Muhammadiyah pada awal terbentuknya hingga waktu penelitian Nakamura (tahun 1970) merupakan salah satu dari perkembangan-perkembangan tersebut. Awal abad ke-19 dan berlangsung hingga kini adalah periode Islamisasi yang ditandai dengan merosotnya ideologi kerajaan. Kekuasaan Mataram melemah setelah gejolak terakhir Perang Jawa pada 1825-1830. Sejalan dengan itu, tampak persentuhan yang semakin sering dengan Hijaz dan Mesir. Komunikasi yang semakin mudah dilakukan dengan perkembangan sarana transportasi menyebabkan para ulama di Nusantara bertambah banyak dalam hal jumlah untuk melakukan ziarah haji di tanah Arab, serta semakin banyak pula pelajar yang dikirim ke Mesir. Sekembalinya dari sana, mereka membawa model Islam di Mekkah dan Mesir, yang dianggap lebih benar dan menambah jumlah kaum reformis yang hendak mengganti hukum adat dan tradisi dengan hukum Islam menurut mereka. Hal yang paling utama adalah memberantas takhayul, yang sering dipahami sebagai hasil kompromi yang terlalu longgar antara Islam denga paganisme yang mendahuluinya (Lombard, 2008c: 346). Berdiri dan berkembangnya Muhammadiyah sendiri merupakan gabungan antara cabang-cabang Muhammadiyah dengan beberapa organisasi lain seperti Ikhwanul Muslimin, Wal Fadri, Hambudi Suci, Khayatul Qulub, Ta'awanu 'alal Birri, dan Priyo Utomo yang pada tahun 1912 menggabungkan diri dengan Muhammadiyah (Nakamura, 1983: 8-9).

Geertz (1983) menyebutkan bahwa abangan adalah satu golongan masyarakat yang mewakili suatu titik berat pada aspek animistis dari sinkretisme Jawa yang melingkupi semuanya, dan secara luas dihubungkan dengan elemen petani. Namun di situ, terdapat sedikit kesalahan anggapan Geertz bahwa ritualritual seperti selametan dalam memperingati kelahiran, khitanan, dan bersih desa termasuk dalam tradisi abangan. Sebenarnya, kategorisasi abangan dan yang bukan abangan memang terpisah garis yang tipis, sehingga sulit membedakan antara keduanya. Namun, dalam kaitannya dengan selametan tersebut, kegiatan itu dilakukan oleh sebagian besar kaum muslim, tidak terkecuali kalangan santri.

Di sini terdapat perbedaan antara Geertz dengan Denys Lombard mengenai batasan-batasan penyebutan kaum abangan. Dalam Le Carrefour Javanais-nya, Lombard mengatakan bahwa ciri abangan, salah satunya adalah 
seperti yang dilakukan pada penganut Saminisme (ajaran kaum Samin) (Lombard, 2008c: 165). Saminisme sendiri adalah gerakan yang dimunculkan oleh pendirinya, Surantiko Samin (1859-1914) yang akhirnya bertahan hingga kini yang bertempat di bagian barat Pegunungan Kendeng (selatan Blora). Samin selalu menjaga jarak dengan Islam dan mulai tahun 1890 dia mulai menyiarkan agama baru yang disebut dengan agama Nabi Adam. Muridnya terus berkembang, dan pada tahun 1907 telah ada sejumlah sekitar 3.000 orang murid. Walaupun kemudian dia dibuang oleh pemerintah kolonial ke Padang dan meninggal di sana, gerakan Saminisme tidak lenyap. Gerakan ini lebih mirip dengan ideologi ratu adil (mesianisme). Mereka tidak mau mengikuti sistem yang diterapkan oleh pemerintah dan menjaga jarak, seperti tidak mau membayar pajak dan menolak kerja rodi. Mereka juga menolak setiap kebijaksanaan Departemen Kehutanan dan beranggapan bahwa segala sumber daya alam adalah milik semua orang (Lombard, 2008c: 160-161).

Dalam contoh kasus lain, yang oleh sebagian orang disalahpahami sebagai kepercayaan abangan bahkan sesat, adalah sejarah Syeh Siti Jenar, yang hidup pada masa adanya Walisongo. Lombard lebih teliti menyebut beberapa alasan "versi Jawa" dengan menyadari perbedaan-perbedaan versi cerita mengenai Syeh Siti Jenar. Ajaran yang diajarkan oleh Syeh Siti Jenar bukanlah hal yang menyimpang, namun lebih pada ketauhidan. Dalam kasus Syeh Siti Jenar ini, penyampaiannya pada masyarakat yang menimbulkan beberapa penyalahartian dan Walisongo mencoba untuk membetulkannya. Syeh Siti Jenar, dan sat unya lagi Sunan Panggung, menjadi menonjol karena perilaku mereka yang nonkonformis. Kisah kedua martir yang disejajarkan oleh para islamolog dengan martir al-Ḥallāj itu terus menjadi bahan renungan buat suatu tradisi Islam marjinal. Tradisi yang menjelajahi hal kebatinan itu dikutuk keras dan dituduh sebagai syirik oleh para pengikut ortodoksi kontemporer, sebagaimana "versi lamanya" dikutuk oleh majelis wali pada zaman dulu (Lombard, 2008c: 344).

Kalangan Islam modernis (dalam hal ini lebih cenderung pada pemaknaan “puritan"), menjadi agak lebih mirip dengan anggapan Geertz dalam pemahaman mengenai perbedaan abangan dengan santrinya. Penganut Islam yang melakukan hal-hal seperti selamatan adalah melakukan praktik yang tidak diajarkan oleh Islam. Tradisi seperti tahlilan yang di dalamnya merupakan kegiatan perkumpulan antara umat muslim dengan memanjatkan doa kepada Allah dianggap sebagai bid'ah dengan dasar pemikiran bahwa dalam ajaran Islam tidak terdapat tahlilan. Hal ini pada dasarnya merupakan pengaruh dari gerakan kaum puritan seperti yang pernah menjadi permasalahan umat muslim setelah kemenangan Ibn Sa'ud di Semenanjung Arab. Pasca tahun 1924, de- 
ngan jatuhnya Hijaz dan sekitarnya ke tangan Ibn Sa'ud, kebijakan untuk memberantas praktik yang tidak sesuai dengan pemikirannya mengenai Islam diterapkan di Arab, di samping juga memberangus tempat-tempat ziarah dan tapak tilas Nabi. Bukan hanya itu, kebebasan untuk bermazhab pun dilarang, dengan dasar bahwa Islam tidak mengenal mazhab. Di sini persoalan yang muncul tidak sederhana. Hal tersebut karena Mekkah adalah tujuan utama umat Islam di dunia untuk melaksanakan ziarah haji. Hingga pada tahun 1928, dibentuk NU, dan mengirimkan delegasinya ke Arab untuk menemui Ibn Sa'ud dan meminta kemerdekaan bermazhab dan dilakukannya giliran antara imamimam salat Jumat di Masjidil Haram (Feillard, 1999: 12).

Pola pengembangan yang dilakukan para pendakwah di Nusantara dengan metode pendidikan pesantren dan kitab kuning ${ }^{4}$ (kitab klasik yang digunakan dalam pesantren) menjadi instrumen yang cukup menjaga "keaslian" ajaran Islam. Penggunaan kitab kuning ini oleh kalangan modernis dianggap sebagai tindakan taqlid (sering ditambahi sebutannya dengan taqlid buta). Hal tersebut merupakan metode pengajaran yang sangat memperhitungkan genealogi keilmuan itu sendiri. Taqlid sering dipahami oleh kalangan modernis terhadap masyarakat tradisionalis sebagai tindakan yang meniru tanpa mau untuk berpikir dan mengembangkan pemahaman. Yang paling menjadi penolakan kaum modernis adalah tidak digunakannya al-Qur'an dan Hadis sebagai satu-sat unya sumber pengetahuan agama Islam. Penolakan kalangan modernis terhadap tradisionalis berasal dari dua hal, yaitu pembelaan tradisionalis terhadap mempertahankannya bentuk tradisi dan penggunaan kitab klasik dalam pemahaman mengenai Islam.

Masyarakat tradisionalis, yang mengidentifikasikan sebagai penganut ahl al-sunnah wa al-jamā'ah, memiliki beberapa perbedaan dalam dasar-dasar akidah. Pada perkembangannya, memang sekarang terdapat beberapa kelompok di Indonesia yang kemudian sama-sama mengatakan bahwa kelompoknya tersebut juga merupakan ahl al-sunnah wa al-jamā'ah, dan mengatakan bahwa yang mereka pegang itu adalah yang paling asli. Namun, kebanyakan menganggap bahwa yang dilakukan kelompok-kelompok tersebut adalah sebagai upaya mendekati masyarakat awam. Pada dasarnya, ahl al-sunnah wa aljamā'ah memiliki arti pengikut Nabi dan memelihara kebersamaan umat. Dasar yang digunakan adalah al-Qur'an, Hadis, ijmā' (kesepakatan para ulama), dan

${ }^{4}$ Kitab kuning ini adalah sebutan bagi kitab klasik yang digunakan kalangan pesantren dalam pengajaran 8 kelompok pelajaran, yaitu nahwu (ilmu mengenai tata bahasa kalimat) dan sharaf (morfologi), fiqh (hukum Islam), ușūl al-fiqh (kaidah hukum Islam), hadis, tafsìr, tauhịd, tasawuf dan etika, dan tarikh (sejarah). 
akal (Ramli, 2009: 185-187). Kebanyakan yang ditentang oleh kelompok modernis adalah penggunaan ijmā' ini sebagai salah satu dasar.

Pada umumnya, perdebatan yang sering dilakukan pada masa panas antara modernis dan tradisionalis yang terjadi awal abad ke-20 berlangsung sebab adanya perbedaan pandangan di antara keduanya. Dalam pernyataan Hurgronje yang dikutip oleh Geertz (1982: 2):

"Islam tradisional di Jawa yang kelihatannya demikian statis dan demikian kuat terbelenggu oleh pikiran-pikiran ulama di abad pertengahan, sebenarnya telah mengalami perubahan-perubahan yang sangat fundamental; tetapi perubahanperibahan tersebut demikian bertahap-tahap, demikianrumit dan demikian dalam tersimpan. Itulah sebabnya bagi para pengamat yang tidak kenal dengan pola pikiran Islam, maka perubahan-perubahan tersebut tidak akan bisa terlihat, walaupun sebenarnya terjadi di depan matanya sendiri, kecuali bagi mereka yang mengamatinya secara seksama."

Persoalan khilāfiyah (perdebatan dalam persoalan tertentu, perbedaan pandangan), yang sebenarnya bukan persoalan prinsipil selalu memunculkan jarak antara kalangan modernis yang menolak secara aktif kondisi yang ada dalam perkembangan Islam. Contohnya, pembacaan qunüt pada waktu salat Subuh, atau pembacaan niat sebelum salat (apakah dilafalkan at au hanya dibaca dalam hati saja). Pada kenyataannya, persoalan yang selalu saja dipermasalahkan tersebut tidak terlalu bermanfaat dilihat dari berbagai sisi.

Gerakan modernis di Indonesia, seperti juga yang ada di tempat lain, bermula dengan soal ubūdiyah (perihal peribadatan). Dalam rangka ini, paham gerakan tersebut berusaha mengubah paham-paham tradisional yang ada. Di dalam tradisionalisme Islam tersebut, menurut kalangan modernis, terdapat takhayul dan khurafat, dan ada pula yang disebut masalah khilāfiyah dalam kalangan Islam (Dhofier, 1982: xiii). Pada tahun 1930-an, Hasjim Asj' arie (Rais Akbar NU) telah mengimbau kepada seluruh umat muslim untuk tidak terlalu mempermasalahkan persoalan kecil ini. Namun, pada perkembangannya, hal tersebut hingga kini masih ada yang mempersoalkan. Pada beberapa kasus, hal ini merambah hingga permasalah politik. Hal yang semacam ini seringkali terjadi pada pencalonan kepala di tingkat desa, hingga terkadang sampai tingkat daerah.

\section{Agama dalam Masyarakat}

Pemahaman mengenai fungsi agama (Islam) dalam bermasyarakat di atas adalah cara melihat agama dalam kaitannya dengan ajaran agama. Hal tersebut dikarenakan agama adalah sesuatu hal yang menjadi pemikiran bukan hanya 
satu orang saja, tetapi menjadi sebuah pemikiran yang terdapat dalam banyak orang, yang pada perkembangannya menjadi melembaga. Kesamaan keimanan (kepercayaan akan sesuatu hal), pada akhirnya menimbulkan kesamaan konsep dan kepentingan. Hal tersebut membentuk institusi dalam masyarakat yang memiliki kaitan erat mengenai persoalan konsep, kebutuhan, kebiasaan (adat dan budaya), dan lebih jauh dapat menimbulkan kondisi, kepentingan, dan keharusan politik di dalamnya.

Pada zaman Nabi Muhammad, pembentukan institusi sosial keagamaan telah begitu tampak. Kondisi yang berkembang pada saat itu adalah teokrasi, yakni pemerintahan bertumpu pada sendi-sendi agama. Walaupun dalam ajaran Islam tidak terdapat keharusan mengenai pembentukan negara Islam, namun kondisi faktual pada saat itu yang berkembang adalah adanya pelaksanaan sistem pemerintahan yang berpegang pada kaidah ajaran agama. Beberapa hal menjadi faktor penyebabnya. Pertama, pertentangan politik antara kaum muslim dengan yang bukan muslim. Pertentangan ini disebabkan oleh karena tekanan pihak bukan muslim kepada kaum muslim, yang memunculkan ikatan sosial di antara mereka sebagai kaum minoritas. Namun demikian, dengan adanya individu Muhammad yang pada saat itu menjadi pemimpin sosial dan agama, perkembangan jumlah kaum muslim yang pesat dan membuat akses yang bersifat minoritas telah hilang, tidak menyebabkan ikat an sosial antara kaum muslim saat itu renggang, namun menjadi keuntungan pembangunan ikatan yang lebih erat lagi.

Kedua, adanya sosok Muhammad yang menjadi panutan saat itu sangat memungkinkan untuk diadakannya sistem pemerintahan teokrasi. Sistem teokrasi tersebut, pada kenyataannya, bukan menjadi sistem yang muncul seperti mekanisme sekarang; di mana terjadi dinamika dan dialektika antarkonsep dan memunculkan satu konsep kuat yang final. Namun, oleh karena sosok Muhammad menjadi panutan pada waktu itu, segala perkataan oleh Muhammad relatif masih dapat dengan mudah diterima oleh masyarakat. Dengan demikian, teokrasi yang ada pada waktu itu lebih dapat dipahami pada keberhasilan personalitas Muhammad dalam mengikat individu-individu dalam lingkungannya pada satu konsepsi mengenai kehidupan sosial mereka.

Pada perkembangan agama Islam dan aspek sosial di masa-masa berikutnya, kondisi yang terbentuk menjadi lebih kompleks. Peningkatan jumlah kaum muslim yang begitu besar di satu sisi, dan telah tidak adanya sosok yang dapat menyatukannya dalam cita-cita sosial bersama, menimbulkan persoalan dalam perbedaan konsep pada kaum muslim. Pada dasarnya, sejak telah tiadanya Muhammad, terlebih lagi sepeninggal para Sahabat, perkembangan agama 
Islam dalam kaitannya dengan kemasyarakatan, telah begitu jauh dari persoalan agama itu sendiri. Faktanya, telah lebih banyak mengacu pada persoalan sosial, ekonomi, dan politik yang masih terbungkus dalam wacana agama oleh para penguasanya.

Sebagai contoh adalah gelombang Islamisme yang muncul pada abad ke20 seiring dengan ekspansi format negara dan sistem pemerintahan modern yang menggantikan sistem kekhalifahan dan bentuk-bentuk pemerintahan feodal lain berbasis kesukuan dan kekeluargaan (Hasan, 2010). Hasan al-Banna (1906-1949) pendiri Ikhwanul Muslimin di Mesir dan Abul Ala Maududi (19031978) sebagai pencetus partai Jama'ati Islami di Indo-Pakistan, mencoba memperkenalkan pemikiran yang mendefinisikan Islam sebagai ideologi politik. Paham tersebutlah yang pada perkembangannya menginspirasi gerakan purifikasi (salafisme) di berbagai negara yang sebelumnya juga telah diperkenalkan oleh 'Abd al-Wahhab (1703-1792) yang lebih populer disebut sebagai gerakan Wahabi, Jamaluddin al-Afghani (1838-1898), Muhammad 'Abduh (18491905), dan Muhammad Rasyid Ridha (1865-1935) (Hasan, 2010: 4).

Islam yang berkembang di Indonesia tetaplah memiliki dinamikanya sendiri, dan relatif berbeda dengan Islam yang ada di tempat lain. Sejarah panjang perkembangan Islam di Indonesia membuat terjadinya persentuhan antara tradisi dan pemikiran lokal Indonesia dengan Islam sebagai jiwa, bukan hanya agama doktriner. Hal tersebut pula yang telah tampak di mata Hurgronje (1992: 4) dalam catatannya mengenai perkembangan budaya dan agama:

...Jika agama tersebut telah dapat meresap ke dalam tulang dan sumsum mereka - dan siapa dapat menyangkalnya? - maka sudah pasti telah terjadi suatu penyesuaian yang tidak membiarkan kedua unsur tersebut tidak berubah.

Anggapan yang dikatakan Hurgronje tersebut sulit dibantah. Terlepas dari penerimaan dan anggapan mereka, fakta bahwa telah terjadi hubungan erat yang tidak saling meniadakan antara agama dan tradisi adalah kondisi yang sudah pasti akan terjadi. Struktur sosial, ekonomi, politik, dan budaya akan mendorong munculnya pola keagamaan yang berbeda dari "pola resmi" sebagaimana tersusun dalam sistem dan aturan yang tertulis dalam kitab fikih sebelum-sebelumnya. Keagamaan kaum pinggiran, misalnya, dan masyarakat umum, seringkali bahkan disebut dengan istilah sinkretisme. Namun demikian, mereka bukan sengaja dan memiliki konsep dari awal untuk mengubah. Hal tersebut terjadi perlahan dan pasti (Mulkhan, 2010: xiv).

Dalam sebuah kasus di sebuah desa di pinggiran Kabupaten Sleman (Yogyakarta), yang oleh penulisnya ditulis dengan nama Desa Mangadeg, 
terlihat dengan jelas kondisi ketika agama telah melebar pengaruhnya dalam sistem adat-tradisi masyarakat setempat (Mu'tasim, 2010). Desa Mangadeg, berada di Sleman, wilayahnya berada tidak begitu jauh dari Kota Yogyakarta sebagai ibukota provinsi. Desa Mangadeg sendiri lokasinya tidak jauh dari pusat kota di Sleman, memungkinkan segala akses dapat masuk. Tetapi, walaupun memiliki akses dengan pusat fasilitas kota dan pemerintahan daerah, Desa Mangadeg tidak dapat pula disebut sebagai wilayah yang maju, karena pada kenyataannya desa ini tingkat pencapaian ekonominya tidak sebaik daerah lainnya di sekitarnya. Namun, walaupun warga dapat dikatakan tidak berada dalam kondisi ekonomi yang mapan, penghargaan terhadap tokoh agama setempat sangatlah tinggi. Pada perkembangannya, tokoh agama setempat mendapatkan akses sumber daya ekonomi dari imbas penghormatan dan posisi stat us sosial mereka terhadap warga. Dalam setiap minggu, tokoh agama memimpin upacara agama yang diadakan masyarakat, dan setiap minggu inilah pemasukan ekonomi diperoleh tokoh agama tersebut. Di Desa Mangadeg ini sendiri, terdapat empat tokoh agama yang berpengaruh: kiai imam masjid, kiai mushala, kiai muda, dan pejabat agama yang diangkat sebelumnya oleh pemerintah (di Jawa, terutama Yogyakarta, pejabat agama yang semacam ini biasanya dipanggil dengan sebutan "Pak Kaum") (Mu'tasim, 2010: 32).

Terdapat sebuah kejadian yang menarik dalam kaitannya dengan penerimaan/penolakan adanya unsur baru yang masuk, dalam hal ini berhubungan dengan tradisi di Desa Mangadeg tersebut. Pernah suatu saat terdapat satu kelompok mahasiswa yang berencana mengadakan pentas Tujuh Belasan, memperingati hari kemerdekaan Indonesia. Memang, secara teknis, acara tersebut dapat dilangsungkan. Namun, perhatian masyarakat dan penerimaan mereka hanya sampai pada mau mendatangi, tanpa sedikit pun tertarik dengan acara "baru" tersebut. Walaupun memang acara Tujuh Belasan bukan hal yang asing bagi mereka karena di tempat lain telah banyak dan biasa dijumpai, di Desa Mangadeg, karena acara tersebut tidak disetujui tokoh agama setempat, terjadi bentuk-bentuk perlawanan. Masyarakat membiarkan acara berlangsung sematamata karena tidak ingin menyinggung para mahasiswa. Namun, perlawanan disampaikan dalam tindakan simbolik, yaitu menarik diri dari keterlibatan dalam acara dan bersikap apatis (Mu'tasim, 2010: 36-37).

Dalam kaitan dengan resistensi masyarakat dan peran kiai dalam "mengontrol" budaya baru yang masuk, mungkin kasus Desa Mangadeg ini dalam beberapa sisi dapat mengingatkan dengan tesis Geertz mengenai anggapannya bahwa kiai adalah cultural broker (makelar budaya). Hal tersebut disebabkan oleh beberapa faktor yang menjadi syarat adanya kondisi masya- 
rakat yang menempatkan kiai sebagai makelar budaya semacam itu. Pertama, tokoh yang paling dijunjung di lingkungan setempat adalah tokoh agama. Kedua, akses informasi yang masuk hanya berasal dari tokoh agama saja tersebut. Sebab yang kedua ini disebabkan pula karena masyarakat yang berada dalam tingkat pendidikan rendah sehingga pemahaman mengenai informasi hanya didapat dari tokoh agama, selain karena mereka telah lama dipercaya.

Namun, kondisi di mana tokoh agama menjadi makelar budaya masyarakat semacam itu, untuk sekarang lambat-laun mulai jarang ditemui walaupun di beberapa tempat masih ada, oleh karena arus informasi pada masyarakat telah berkembang, dan kiai bukan lagi merupakan satu-sat unya sumber informasi. Dalam kondisi semacam ini, sebagai contoh ekstrem, di mana informasi tidak hanya diperoleh hanya dari satu figur saja, kiai sebagai makelar budaya tidak begitu ketara, kalau tidak dikatakan bahwa teori itu tidak berlaku. Namun, bukan berarti bahwa karisma kiai begitu saja hilang. Tradisi masyarakat berhubungan kebiasaan dan pengaruh agama, dalam banyak hal dapat menyelamatkan mereka dari konflik dan dalam pergesekan sosial lainnya.

\section{E. Simpulan}

Pola masyarakat Jawa yang menampakkan kekagumannya pada hal yang di luar kebiasaan dan hukum alam pada saat itu (yang terlihat seperti kelebihan mistik) menjadi salah satu faktor yang mendorong orang tertarik untuk menjadi pengikut Gerakan dakwah yang digunakannya memiliki tujuan untuk mengubah pola pikir dan pengetahuan masyarakat Jawa, yang oleh mereka lebih dianggap penting daripada sekadar mengubah (mengislamkan) bentuk fisik yang terlihat mata saja seperti melarang adat-tradisi yang dirasa tidak diajarkan Islam. Alih-alih demikian, adat dan tradisi adalah hal yang dilihat sebagai sesuatu yang sama sekali tidak bertentangan dengan Islam, karena Islam adalah agama yang berarti bukan pada bentuk, namun pada jiwa (penjiwaan) dan dasar pikir segala aktivitas dalam kehidupan manusia dan bermasyarakat.

Persentuhan antara agama dan masyarakat menjadi sulit untuk diidentifikasi. Agama mempengaruhi tradisi, begitu pula tradisi setempat mempengaruhi pola pikir dan tindakan dalam koridor keagamaan. Tradisi yang telah erat kaitannya dengan agama yang berkembang di masyarakat dapar menjadi instrumen dalam rekonsiliasi konflik yang terjadi. Walaupun demikian, di beberapa contoh yang kasuistik, terdapat ekses dari persentuhan antara tradisi dan agama jika di situ terdapat campur-tangan politik, seperti pada pertentangan antara modernis-tradisionalis yang diperumit oleh politisasi isu. 
Kasus di Desa Mangadeg dapat menjadi salah satu kasus di mana kiai menjadi figur yang diposisikan dalam puncak masyarakat. Masyarakat setempat mendapatkan segala informasi dari dirinya. Kiai atau tokoh agama, dalam masyarakat yang sesuai dengan beberapa syarat masyarakat Desa Mangadeg, akan diposisikan sebagai "cultural broker". Namun, dalam masyarakat yang lain, situasi serupa tidak dapat dijumpai, walaupun dalam hal karisma dan pengaruh pembentukan budaya oleh kiai masih begitu tampak.

\section{Daftar Pustaka}

Anasom. 2000. "Sejarah Masuknya Islam di Jawa", dalam Amin, M. Darori (Ed.). 2000. Islam dan Kebudayaan Jawa. Yogyakarta: Gama Media.

Azra, Azyumardi. 2005. Jaringan Ulama Timur Tengah dan Kepulauan Nusantara Abad XVII dan XVIII. Jakarta: Kencana.

Dhofier, Zamakhsyari. 1982. Tradisi Pesantren: Studi tentang Pandangan Hidup Kyai. Jakarta: LP3ES.

Feillard, Andree. 1999. NU vis-a-vis Negara, terj. Yogyakarta: LKiS.

Geertz, Clifford. 1983. Abangan, Santri, dan Priyayi dalam Masyarakat Jawa, terj. Jakarta: Dunia Pustaka Jaya.

Hasan, Noorhaidi. 2010. "Ideologi, Identitas, dan Ekonomi Politik Kekerasan", dalam Prisma Vol. 29, No. 4, Oktober 2010.

Hurgronje, C. Snouck. 1992. Kumpulan Karangan Snouck Hurgronje, Jilid VII, terj. Jakarta: INIS.

Lombard, Denys. 2008a. Nusa Jawa: Silang Budaya. Batas-batas Pembaratan, terj. Jakarta: Gramedia Pustaka Utama.

2008b. Nusa Jawa: Silang Budaya. Jaringan Asia, terj. Jakarta: Gramedia Pustaka Utama.

2008c. Nusa Jawa: Silang Budaya. Warisan KerajaanKerajaan Konsentris, terj. Jakarta: Gramedia Pustaka Utama.

Mulkhan, Abdul Munir. 2010. "Dinamika Sosial Islam”, sebagai Kata Pengantar dalam Mu’tasim, Radjasa. 2010. Perlawanan Santri Pinggiran. Yogyakarta: Insan Madani.

Mu'tasim, Radjasa. 2010. Perlawanan Santri Pinggiran. Yogyakarta: Insan Madani.

Nakamura, Mitsuo. 1983. Bulan Sabit Muncul dari Balik Pohon Beringin; Studi tentang Pergerakan Muhammadiyah di Kotagede, Yogyakarta, terj. Yogyakarta: Gadjah Mada University Press. 
Ramli, Muhammad Idrus. 2009. Madzhab al-Asy'ari, Benarkah Ahlussunnah wal Jama'ah? Surabaya: Khalista - LTN NU Jawa Timur.

Ridwan, et al. 2008. Islam Kejawen. Purwokerto: STAIN Purwokerto Press.

Simuh. 2004. "Interelasi Islam dan Budaya Jawa", dalam SOFWAN, Ridin, et al. 2004. Merumuskan Kembali Interelasi Islam-Jawa. Yogyakarta: Gama Media.

Sofwan, Ridin, et al. 2004. Islamisasi di Jawa; Walisongo, Penyebar Islam di Jawa, Menurut Penuturan Babad. Yogyakarta: Pustaka Pelajar. 